\title{
FAKTOR DEMOGRAFI, FAKTOR PENYAKIT, DAN FAKTOR PSIKOLOGIS TERHADAP MAKNA SPIRITUAL PENGALAMAN SAKIT PADA ODHA
}

\author{
Nurhayati $^{1}$, Rohman Azzam ${ }^{2}$, Mustikasari ${ }^{3}$ \\ Universitas Muhammadiyah Jakarta ${ }^{1,2}$ \\ Universitas Indonesia $^{3}$ \\ nurhayatideanur@gmail.com ${ }^{1}$
}

\begin{abstract}
ABSTRAK
Penelitian ini bertujuan untuk mengidentifikasi hubungan faktor demografi (usia, jenis kelamin, pendidikan terakhir, pekerjaan, agama, status ekonomi, status perkawinan), faktor penyakit (awal diagnosa, infeksi oportunistik, kepatuhan minum obat) dan faktor psikologi (cemas dan depresi) dengan makna spiritual pengalaman sakit pada orang dengan HIV/AIDS (ODHA) di Jakarta Timur. Metode penelitian ini menggunakan metode deskriptif analitik dengan pendekatan cross sectional study. Hasil penelitian ini pada analisis bivariate diperoleh $\mathrm{p}$ value 0,043 artinya ada hubungan antara usia dengan makna spiritual pengalaman sakit, pada analisis multivariate diperoleh Infeksi oportunistik merupakan faktor dominan berhubungan dengan makna spiritual pengalaman sakit. Simpulan, infeksi oportunistik merupakan faktor dominan berhubungan dengan makna spiritual pengalaman sakit.
\end{abstract}

Kata Kunci: Demografi, Makna Spiritual, ODHA, Penyakit, Psikologi

\begin{abstract}
This study aims to identify the relationship between demographic factors (age, gender, latest education, occupation, religion, economic status, marital status), disease factors (initial diagnosis, opportunistic infections, medication adherence), and psychological factors (anxiety and depression). the spiritual meaning of the experience of illness in people with HIV I AIDS (PLWHA) in East Jakarta. This research method uses a descriptive-analytic method with a cross-sectional study approach. The results of this study in the bivariate analysis obtained a p-value of 0.043, meaning that there is a relationship between age and the spiritual meaning of the experience of pain, in the multivariate analysis, opportunistic infections are the dominant factor associated with the spiritual meaning of pain experiences. In conclusion, opportunistic infections are the dominant factor related to the spiritual meaning of the experience of pain.
\end{abstract}

Keywords: Demography, Spiritual Meaning, PLWHA, Illness, Psychology

\section{PENDAHULUAN}

Penyakit HIV merupakan masalah kesehatan masyarakat yang serius di seluruh dunia termasuk Indonesia (Andri et al., 2020; Sididi et al., 2020). Stigma dan diskriminasi masyarakat terhadap orang dengan HIV/AIDS (ODHA) berkembang secara luas, berakibat memburuknya kondisi ODHA baik fisik maupun psikologis (Sarkar et al., 2019). Hal ini berdampak pada perilaku ODHA yang menyembunyikan status HIV takut untuk melakukan test HIV dan menunda pengobatan (Mahaendriningtiyastuti et al., 2018; Wicaksono et al., 
2018). Banyak ODHA menginternalisasi stigma terhadap dirinya, menarik diri dari interaksi sosial dan menganggap sakit HIV yang dideritanya merupakan kondisi negatif, yang dimanifestasikan dalam bentuk perilaku negatif (Syahrina \& Pranata, 2018; Purwandari et al., 2019). Hal ini sejalan dengan penelitian Lin et al., (2017) di Singapura bahwa ODHA yang memaknai sakit negatif cenderung menarik diri dari kehidupan sosial dan merasa malu yang berlebihan (Lin et al., 2017; Andri et al., 2020).

Tahun 2018 terdapat 37,9 juta orang di dunia terinfeksi HIV, 770.000 orang meninggal. Di Asia Pasifik 5,9 juta orang, 200.000 orang meninggal. Di Indonesia tahun 2017 terdapat 27.975 orang terinfeksi HIV dan 9.280 AIDS (Kemenkes RI, 2018). Indonesia menempati urutan ke-3 tertinggi di Asia Pasifik setelah Afghanistan dan Bangladesh (UNAIDS, 2019). Provinsi DKI Jakarta urutan kedua setelah Provinsi Jawa Timur untuk kasus HIV dan urutan ke-6 dari 34 provinsi yang ada di Indonesia untuk kasus AIDS. Jakarta Timur menempati urutan ke-2 setelah Jakarta Pusat (Kemenkes RI, 2018). Jumlah kasus baru HIV positif yang dilaporkan dari tahun ketahun cenderung meningkat dan pada tahun 2017 dilaporkan sebanyak 48.300 kasus (Kemenkes RI, 2018; Sididi et al., 2020).

Dalam suasana hati yang sedih, takut dan cemas akan kematian, religuisitas dan spiritualitas menjadi pegangan hidup, praktik keagamaan menjadi akitivitas dalam keseharian (Andrianto1 et al., 2019). Hal ini merupakan langkah mendekatkan diri kepada Tuhan yang berdampak pada pemaknaan pengalaman sakit positif (Prasojo, 2017; Amin et al., 2019; Amin et al., 2020).

Depresi muncul sebagai dampak stigma dan diskriminasi masyarakat yang menilai bahwa ODHA adalah manusia pendosa, sedangkan dihukum karena perbuatannya sehingga harus dijauhi, hal ini sangat menyulitkan ODHA untuk melakukan aktivitas yang biasa dikerjakan sebelum terinfeksi HIV, situasi ini berdampak pada psikologi ODHA, mereka merasakan penyesalan yang mendalam, marah, kecewa, bingung, putus asa dan tidak mempunyai harapan lagi untuk masa depan. Religiusitas berperan dalam mengurangi depresi (Prasojo, 2017).

Banyak faktor yang berpengaruh terhadap kemampuan ODHA dalam menemukan makna spiritual pengalaman sakit. Namun pada penelitian ini melakukan study literature tentang bagaimana hubungan faktor demografi (usia, jenis kelamin, pendidikan terakhir, pekerjaan, agama, status ekonomi, status perkawinan), faktor penyakit (awal diagnosa, infeksi oportunistik dan kepatuhan minum obat) dan faktor psikologis (cemas dan depresi) dengan kemampuan menemukan makna spiritual pengalaman sakit.

\section{METODE PENELITIAN}

Penelitian ini menggunakan rancangan deskriptif analitik dengan pendekatan cross sectional study. Pengambilan data dilakukan secara online melalui google formulir. Kuisioner yang digunakan terdiri dari kuisioner karakteristik demografi, Moresky Medication Adherence Scalae (MMAS-8), Beck Anxiety Inventoty (BAI), Beck Depression Inventory II (BDI) dan makna spiritual pengalaman sakit (dikembangkan oleh peneliti berdasarkan penelitian terkait). Kuisioner demografi terdiri dari 9 (sembilan) item pertanyaan, 7 (tujuh) pertanyaan karakteristik responden, yaitu untuk mengetahui usia, jenis kelamin, pendidikan terakhir, pekerjaan, agama status ekonomi, status perkawinan dan 2 (dua) pertanyaan terkait penyakit yaitu mulai terdiagnosa HIV dan infeksi oportunistik. Kuisioner MMAS-8 terdiri dari 8 pernyataan tentang kepatuhan minum obat, BAI dan BDI masing-masing terdiri dari 21 pernyataan terkait cemas dan depresi dan makna spiritualitas terdiri dari 17 item pertanyaan terkait makna spiritualitas terhadap pengalaman sakit yang di adop berdasarkan pendapat dari beberapa ahli. 
Hasil uji validitas dan reliabilitas MMAS-8, BAI, BDI dan makna spiritual semua item pertanyaan mempunyai nilai $r$ hasil $>r$ tabel $(0,361)$, artinya semua pernyataan dinyatakan valid secara statistik, dengan nilai cronbach alpha 0,96 (MMAS-8), 0,918 (BAI), 0,929 (BDI) dan 0,987 (Makna spiritual), artinya instrument dinyatakan reliabel.

\section{Populasi dan Sampel Penelitian}

Populasi dan sampel dalam penelitian ini adalah pasien HIV Poliklinik Matahari Rumah Sakit Bhayangkara Tingkat I Jakarta Timur. Teknik sampling yang digunakan non probability sampling dengan consecutive sampling, jumlah sampel 225 responden, dipilih sesuai dengan kriteria inklusi yang ditetapkan yaitu bersedia menjadi responden, mengerti bahasa Indonesia, mengetahui status dirinya positif HIV, usia 20-49 tahun dan dalam pengobatan anti retroviral.

\section{Tahapan Penelitian}

Setelah melalui sidang proposal, peneliti mengajukan uji etik penelitian ke Fakultas Keperawatan Universitas Muhammadiyah Jakarta (UMJ), permohonan uji etik disetujui dengan hasil penelitian layak untuk dilakukan (SK Lolos Kaji Etik no: 0458/F-9UMJ/IV/2020). Mengajukan permohonan izin penelitian kepada pimpinan rumah sakit, penelitian diijinkan dengan surat (SK No: B/2670/V/2020/RS.BHAY.TK.1). Dalam proses pengumpulan data peneliti dibantu oleh 2 (dua) orang enumerator yaitu 1 (satu) orang petugas Poliklinik Matahari dan 1 (satu) orang petugas Lembaga Swadaya Masyarakat yang mengelola pasien HIV di Poliklinik Matahari.

\section{Analisis Data}

Data diolah dan dikelompokkan berdasarkan analisis univariat, bivariate dan multivariate.

\section{HASIL PENELITIAN}

\section{Analisis Univariat}

Tabel. 1

Distribusi Frekuensi Responden Berdasarkan Faktor Demografi (Usia) Juli $2020(n=225)$

\begin{tabular}{cccccc}
\hline Variabel & Mean & Median & Standar Deviasi & Minimal & Maksimal \\
\hline Usia & 34,84 & 34,00 & 7,867 & 21 & 49 \\
\hline
\end{tabular}

Berdasarkan tabel 1 menunjukkan bahwa rata-rata usia responden 34,84 tahun, termuda 21 tahun dan usia tertua 49 tahun.

Tabel. 2

Distribusi Frekuensi Responden Berdasarkan Faktor Demografi (Jenis Kelamin, Pendidikan Terakhir, Pekerjaan, Agama, Status Ekonomi, Status Perkawinan)

\begin{tabular}{ccc}
\hline \multicolumn{1}{c}{ Variabel } & Jumlah & Persentase (\%) \\
\hline Jenis Kelamin: & & \\
$-\quad$ Laki-laki & 167 & 74,2 \\
$-\quad$ Perempuan & 58 & 25,8 \\
\hline
\end{tabular}




\begin{tabular}{|c|c|c|}
\hline Pendidikan Terakhir: & 1 & 0,4 \\
\hline - Tidak Sekolah & 9 & 4 \\
\hline$-\quad S D$ & 21 & 9,3 \\
\hline - $\quad$ SMP & 124 & 55,1 \\
\hline - $\quad$ SMA & 70 & 31,1 \\
\hline - PT & & \\
\hline \multicolumn{3}{|l|}{ Pekerjaan: } \\
\hline - Tidak Bekerja & 59 & 26,2 \\
\hline - Petani & - & - \\
\hline - Buruh/Karyawanm Swasta & 101 & 44,9 \\
\hline - Wiraswasta/Dagang & 44 & 19,6 \\
\hline - $\quad$ PNS/TNI/POLRI & 21 & 9,3 \\
\hline \multicolumn{3}{|l|}{ Agama: } \\
\hline - Islam & 208 & 92,4 \\
\hline - Kristen & 14 & 6,2 \\
\hline - Protestan & 2 & 0,9 \\
\hline - $\quad$ Hindu & - & - \\
\hline - $\quad$ Budha & 1 & 0,4 \\
\hline - $\quad$ Kong $\mathrm{Hu} \mathrm{Cu}$ & - & - \\
\hline \multicolumn{3}{|l|}{ Status Ekonomi: } \\
\hline - Pendapatan $\leq 4$ juta/bulan & 121 & 53,8 \\
\hline - $\quad$ Penapatan > 4 juta/bulan & 92 & 40,9 \\
\hline - Lainnya & 12 & 5,3 \\
\hline \multicolumn{3}{|l|}{ Status perkawinan: } \\
\hline - Belum/tidak Menikah & - & - \\
\hline - $\quad$ Menikah & 187 & 83,1 \\
\hline - Janda/Duda & 38 & 16,9 \\
\hline
\end{tabular}

Berdasarkan tabel 2 menunjukkan mayoritas responden berjenis kelamin laki-laki yaitu 167 orang (74,2\%), pendidikan terakhir SMA 124 orang $(55,1 \%)$, bekerja sebagai buruh/karyawan swasta 101 orang (44,9\%), agama islam 208 orang $(92,4 \%)$, pendapatan kurang dari Rp. 4 juta/bulan 121 orang $(53,8 \%)$, dan status menikah 187 orang $(83,1 \%)$.

Tabel. 3

Distribusi Frekuensi Responden Berdasarkan Faktor Penyakit (Awal Diagnosa) Juli $2020(n=225)$

\begin{tabular}{cccccc}
\hline Variabel & Mean & Median & Standar Deviasi & Minimal & Maksimal \\
\hline Awal Diagnosa & 4,49 & 3,00 & 4,306 & 0 & 27 \\
\hline
\end{tabular}

Berdasarkan tabel 3 menunjukkan bahwa berdasarkan awal diagnosa atau lamanya terinfeksi virus HIV didapatkan rata-rata pasien sudah terdiagnosa HIV 4,49 tahun.

Tabel. 4

Distribusi Frekuensi Responden Berdasarkan Faktor Penyakit (Infeksi Oportunistik dan Kepatuhan Minum Obat)

\begin{tabular}{ccc}
\hline \multicolumn{1}{c}{ Variabel } & Jumlah & Persentase (\%) \\
\hline Infeksi Oportunistik: & & \\
$-\quad$ Tidak ada & 137 & 60,9 \\
- $\quad$ Ada & 88 & 39,1 \\
\hline Kepatuhan Minum Obat: & 54 & \\
- Rendah & 77 & 24 \\
- Sedang & 94 & 34,2 \\
$-\quad$ Tinggi & & 41,8 \\
\hline
\end{tabular}


Berdasarkan tabel 4 menunjukkan bahwa kejadian infeksi oportunistik, sebagian besar 137 orang $(60,9 \%)$ responden tidak disertai infeksi opportunistik, 94 orang $(41,8 \%)$ mempunyai tingkat kepatuhan minum obat yang tinggi.

Tabel. 5

Distribusi Frekuensi Responden Berdasarkan

Faktor Psikologis (Cemas dan Depresi)

\begin{tabular}{clccc}
\hline & Variabel & Jumlah & Persentase (\%) \\
\hline Cemas: & & & \\
- & Ringan & 200 & 88,9 \\
- & Sedang & 22 & 9,8 \\
- & Berat & 3 & 1,3 \\
\hline Depresi: & & & \\
- & Ringan & 192 & 85,3 \\
- & Sedang & 31 & 13,8 \\
- & Berat & 2 & 0,9 \\
\hline
\end{tabular}

Berdasarkan tabel 5 menunjukkan bahwa sebagian besar responden mengalami cemas ringan yaitu 200 orang $(88,9 \%)$, sebagian besar responden mengalami depresi ringan yaitu 192 orang $(85,3 \%)$.

Tabel. 6

Distribusi Frekuensi Responden

Berdasarkan Makna Spiritual

\begin{tabular}{ccc}
\hline \multicolumn{1}{c}{ Variabel } & Jumlah & Persentase (\%) \\
\hline Makna Spiritual pengalaman Sakit: & & \\
$-\quad$ Negatif & 66 & 29,3 \\
$-\quad$ Positif & 159 & 70,7 \\
\hline
\end{tabular}

Berdasarkan tabel 6 menunjukkan perbedaan yang sangat mencolok antara ODHA yang memaknai pengalaman sakit positif dan ODHA yang memaknai pengalaman sakit secara negatif, sebagian besar yaitu sebanyak 159 orang $(70,7 \%)$ ODHA memaknai pengalaman sakit positif.

\section{Analisis Bivariate}

Tabel. 7

Hubungan Faktor Demografi (Usia)

dengan Makna Spiritual Pengalaman Sakit

\begin{tabular}{ccccccc}
\hline Variabel & Makna Spiritual & Mean & SD & SE & P value & N \\
\hline Usia & Negatif & 33,0 & 7,730 & 0,952 & & 66 \\
& Positif & 35,52 & 7,846 & 0,622 & 0,043 & 159 \\
\hline
\end{tabular}

Berdasarkan tabel 7 menunjukkan bahwa hasil uji beda dua mean $\mathrm{t}$ independent diperoleh $\mathrm{p}$ value 0,043 artinya ada hubungan antara usia dengan kemampuan menemukan makna spiritual pengalaman sakit. 
Tabel. 8

Hubungan Faktor Demografi (Jenis Kelamin, Pendidikan Terakhir, Pekerjaan, Agama, Status Ekonomi dan Status Perkawinan) dengan Makna Spiritual Pengalaman Sakit

\begin{tabular}{|c|c|c|c|c|c|c|c|}
\hline \multirow[t]{3}{*}{ Kategori } & \multicolumn{4}{|c|}{$\begin{array}{c}\text { Makna Spiritual } \\
\text { pengalaman Sakit }\end{array}$} & \multirow[t]{3}{*}{$\sum$} & \multirow{3}{*}{$\begin{array}{c}\mathrm{P} \\
\text { Value }\end{array}$} & \multirow{3}{*}{$\begin{array}{c}\text { OR } \\
95 \% \mathrm{CI}\end{array}$} \\
\hline & \multicolumn{2}{|c|}{ Negatif } & \multicolumn{2}{|c|}{ Positif } & & & \\
\hline & $\mathrm{N}$ & $\%$ & $\mathrm{~N}$ & $\%$ & & & \\
\hline \multicolumn{8}{|l|}{ Jenis Kelamin: } \\
\hline - Laki-laki & 55 & 32,9 & 112 & 67,1 & 167 & 0,07 & 2,1 \\
\hline - $\quad$ Perempuan & 11 & 19 & 47 & 81 & 58 & & \\
\hline \multicolumn{8}{|l|}{ Pendidikan Terakhir: } \\
\hline - $\quad$ Pendidikan Dasar & 3 & 30 & 7 & 70 & 10 & 0,93 & 0,93 \\
\hline - $\quad$ Pendidikan Menengah & 43 & 29,7 & 102 & 70,3 & 145 & & \\
\hline - $\quad$ Pendidikan Tinggi & 20 & 28,6 & 50 & 71,4 & 70 & $0,87 \mathrm{P}$ & $0,95 \mathrm{P}$ \\
\hline \multicolumn{8}{|l|}{ Pekerjaan: } \\
\hline - Tidak bekerja & 17 & 28,8 & 42 & 71,2 & 59 & $\mathrm{P}$ & $\mathrm{P}$ \\
\hline \multirow{3}{*}{$\begin{array}{ll}\text { - } & \text { Buruh/Karyawan swasta + } \\
\text { Wiraswasta/dagang } \\
\text { - } & \text { PNS/TNI/POLRI }\end{array}$} & 46 & 31,7 & 99 & 68,3 & 145 & 0,68 & 0,87 \\
\hline & 3 & 14,3 & 18 & 85,7 & 21 & & \\
\hline & & & & & & 0,2 & 2,43 \\
\hline \multicolumn{8}{|l|}{ Agama: } \\
\hline - Islam & 63 & 30,3 & 145 & 69,7 & 208 & 0,41 & 2,03 \\
\hline - $\quad$ Non Islam & 3 & 17,6 & 14 & 82,4 & 17 & & \\
\hline \multicolumn{8}{|l|}{ Status Ekonomi: } \\
\hline - Pendapatan $\leq 4$ Juta/bulan & 42 & 31,6 & 91 & 68,4 & 133 & 0,46 & 1,31 \\
\hline - Pendapatan $>4$ juta /bulan & 24 & 16,1 & 68 & 73,9 & 92 & & \\
\hline \multicolumn{8}{|l|}{ Status Perkawinan: } \\
\hline - Menikah & 58 & 31 & 129 & 69 & 187 & 0,30 & 1,69 \\
\hline - Janda/Duda & 8 & 21,1 & 30 & 78,9 & 38 & & \\
\hline
\end{tabular}

Berdasarkan tabel 8 menunjukkan bahwa hasil uji statistik chi square didapatkan tidak ada hubungan antara jenis kelamin, pendidikan terakhir, pekerjaan, agama, status ekonomi dan status perkawinan dengan makna spiritual pengalaman sakit.

Tabel. 9

Hubungan Faktor Penyakit (Awal Diagnosa) dengan Makna Spiritual Pengalaman Sakit

\begin{tabular}{ccccccc}
\hline Variabel & Makna Spiritual & Mean & SD & SE & P value & N \\
\hline Awal & Negatif & 4,79 & 4,904 & 0,604 & & 66 \\
Diagnosa & Positif & 4,36 & 4,043 & 0,321 & 0,503 & 159 \\
\hline
\end{tabular}

Berdasarkan tabel 9 hasil uji beda dua mean $t$ independent pada tabel 9 diperoleh $\mathrm{p}$ value 0,503 yang artinya pada alpha $5 \%$ tidak ada perbedaan yang bermakna rata-rata lama terdiagnosa HIV antara responden yang menemukan makna spiritual pengalaman sakit positif dengan responden yang menemukan makna spiritual pengalaman sakit negatif. 
Tabel. 10

Hubungan Faktor Penyakit (Infeksi Oportunistik dan Kepatuhan Minum Obat) dengan Makna Spiritual Pengalaman Sakit

\begin{tabular}{|c|c|c|c|c|c|c|c|c|}
\hline \multirow{3}{*}{\multicolumn{2}{|c|}{ Kategori }} & \multicolumn{4}{|c|}{ Makna Spiritual pengalaman Sakit } & \multirow{3}{*}{$\sum$} & \multirow{3}{*}{$\begin{array}{c}\mathrm{P} \\
\text { Value }\end{array}$} & \multirow{3}{*}{$\begin{array}{c}\text { OR } \\
95 \% \mathrm{CI}\end{array}$} \\
\hline & & \multicolumn{2}{|c|}{ Negatif } & \multicolumn{2}{|c|}{ Positif } & & & \\
\hline & & $\mathrm{N}$ & $\%$ & $\mathrm{~N}$ & $\%$ & & & \\
\hline \multicolumn{9}{|c|}{ Infeksi Oportunities: } \\
\hline \multirow{2}{*}{-} & Tidak ada & 47 & 34,3 & 90 & 65,7 & 137 & 0,06 & 1,9 \\
\hline & Ada & 19 & 21,6 & 69 & 78,4 & 88 & & \\
\hline \multirow{3}{*}{\multicolumn{2}{|c|}{$\begin{array}{cc}\text { Kepatuhan Minum Obat: } & \text { Rendah } \\
- & \text { Sedang } \\
- & \text { Tinggi }\end{array}$}} & 16 & 29,6 & 38 & 70,4 & 54 & 0,77 & 1,11 \\
\hline & & 20 & 26,0 & 57 & 74,0 & 77 & 04 & 134 \\
\hline & & 30 & 31,9 & 64 & 68,1 & 94 & $\begin{array}{c}0,+ \\
P\end{array}$ & $\mathrm{P}$ \\
\hline
\end{tabular}

Berdasarkan tabel 10 hasil uji chi-square pada tabel 10 diperoleh p value 0,06 artinya tidak ada hubungan antara infeksi oportunistik dengan kemampuan menemukan makna spiritual pengalaman sakit, dengan Odds ratio 1,9 artinya responden yang sudah terinfeksi oportunistik memiliki peluang sebanyak 1,9 kali untuk menemukan makna spiritual pengalaman sakit yang positif dibanding responden yang tidak terinfeksi oportunistik.

Hasil uji regresi logistik sederhana (dummy variabel) diperoleh p value 0,77 untuk kelompok responden yang memiliki kepatuhan rendah dan kepatuhan tinggi dan $\mathrm{p}$ value 0,4 untuk kelompok responden yang memiliki kepatuhan sedang dan kepatuhan tinggi, artinya tidak ada hubungan antara tingkat kepatuhan rendah, sedang dan tinggi dengan kemampuan menemukan makna spiritual pengalaman sakit.

Tabel.11

Hubungan Faktor Psikologis (Cemas dan Depresi) dengan Makna Spiritual Pengalaman Sakit

\begin{tabular}{|c|c|c|c|c|c|c|c|c|}
\hline \multirow{3}{*}{\multicolumn{2}{|c|}{ Kategori }} & \multicolumn{4}{|c|}{$\begin{array}{c}\text { Makna Spiritual } \\
\text { Pengalaman Sakit }\end{array}$} & \multirow[t]{3}{*}{$\sum$} & \multirow[t]{3}{*}{$\mathrm{P}$} & \multirow[t]{3}{*}{ OR $95 \% \mathrm{CI}$} \\
\hline & & \multicolumn{2}{|c|}{ Negatif } & \multicolumn{2}{|c|}{ Positif } & & & \\
\hline & & $\mathrm{N}$ & $\%$ & $\mathrm{~N}$ & $\%$ & & & \\
\hline \multicolumn{9}{|l|}{ Cemas: } \\
\hline- & Ringan & 57 & 28,5 & 143 & 71,5 & 200 & 0,999 & 1 \\
\hline \multirow{2}{*}{$\begin{array}{l}- \\
-\end{array}$} & Sedang & 9 & 40,9 & 13 & 59,1 & 22 & $\mathrm{P}$ & $\mathrm{P}$ \\
\hline & & 0 & 0 & 3 & 100 & 3 & 0,23 & 1,74 \\
\hline \multicolumn{9}{|c|}{ Depresi: } \\
\hline- & Ringan & 54 & 28,1 & 138 & 71,9 & 192 & 0,33 & 1,48 \\
\hline- & Sedang & 11 & 35,5 & 20 & 64,5 & 31 & $\mathrm{P}$ & $\mathrm{P}$ \\
\hline- & Berat & 1 & 50 & 1 & 50 & 2 & 0,70 & 0,57 \\
\hline
\end{tabular}

Berdasarkan tabel 11 menjelaskan hasil uji regresi logistik sederhana (dummy variabel) diperoleh p value 0,999 untuk kelompok responden yang mengalami cemas berat dan cemas sedang dan $\mathrm{p}$ value 0,23 untuk kelompok responden yang mengalami cemas ringan dan cemas sedang, artinya tidak ada hubungan antara cemas ringan, sedang dan berat dengan kemampuan menemukan makna spiritual pengalaman sakit. 


\section{Analisis Multivariate}

Tabel. 12

Faktor-Faktor yang Berhubungan

dengan Makna Spiritual Pengalaman Sakit

\begin{tabular}{|c|c|c|}
\hline No & Variabel & P Value \\
\hline 1 & Usia & 0.131 \\
\hline 2 & Jenis Kelamin & 0.070 \\
\hline 3 & Pendidikan Terakhir & 0,324 \\
\hline 4 & Pekerjaan & 0,313 \\
\hline 5 & Agama & 0,430 \\
\hline 6 & Status Ekonomi & 0,843 \\
\hline 7 & Status Perkawinan & 0,855 \\
\hline 8 & Awal Diagnosa & 0,484 \\
\hline 9 & Infeksi Oportunistik & 0,084 \\
\hline 10 & Kepatuhan Minum Obat & 0,722 \\
\hline 11 & Cemas & 0,855 \\
\hline 12 & Depresi & 0,783 \\
\hline
\end{tabular}

Berdasarkan seleksi bivariate pada tabel 12 diperoleh tiga variabel yaitu variabel usia, jenis kelamin dan infeksi oportunistik yang mempunyai nilai $\mathrm{p}$ value $<0,25$, artinya ada hubungan yang bermakna antara usia, jenis kelamin dan infeksi oportunistik dengan makna spiritual pengalaman sakit. Ketiga variabel tersebut memenuhi syarat untuk menjadi kandidat pada pemodelan multivariate.

Tabel. 13

Uji Interaksi Variabel Jenis Kelamin dan Infeksi Oportunistik

\begin{tabular}{lcccccccc}
\hline & & & & & $\mathrm{P}$ & & \multicolumn{2}{c}{$95 \%$ CI } \\
\cline { 6 - 9 } \multicolumn{1}{c}{ Variabel } & Koefisien & S.E & Wald & df & Value & OR & Min & Max \\
\hline Jenis Kelamin & $-0,408$ & 0,426 & 0,917 & 1 & 0,338 & 0,665 & 0,289 & 1,532 \\
\hline $\begin{array}{l}\text { Infeksi } \\
\text { Oportunistik }\end{array}$ & $-0,433$ & 0,345 & 1,574 & 1 & 0,210 & 0,649 & 0,330 & 1,276 \\
\hline JK*IO & 1,656 & 1,142 & 2,102 & 1 & 0,147 & 5,239 & 0,558 & 49,168 \\
\hline
\end{tabular}

Berdasarkan tabel 13 menunjukkan hasil uji interaksi antara variabel jenis kelamin dan variabel infeksi oportunistik diperoleh p value > 0,05 yaitu 0,095 artinya tidak ada interaksi antara jenis kelamin dan infeksi oportunistik, oleh karena hasil analisis tidak ada interaksi, maka pemodelan ini valid secara statistic.

Tabel. 14

Pemodelan Akhir Variabel Jenis Kelamin dan Infelksi Oportunistik dengan Variabel Makna spiritual Pengalaman Sakit

\begin{tabular}{lcccccccc}
\hline \multirow{2}{*}{ Variabel } & \multirow{2}{*}{ Koefisien } & \multirow{2}{*}{ S.E } & \multirow{2}{*}{ Wald } & df & P Value & OR & \multicolumn{2}{c}{ 95\% CI } \\
\cline { 6 - 9 } & & & & & & & Min & Max \\
Jenis & $-0,765$ & 0,376 & 4,124 & 1 & 0,042 & 0,466 & 0,223 & 0,964 \\
\hline $\begin{array}{l}\text { Infeksi } \\
\text { Oportunistik }\end{array}$ & $-0,661$ & 0,318 & 4,304 & 1 & 0,038 & 0,517 & 0,277 & 1,019 \\
\hline
\end{tabular}


Berdasarkan tabel 14 dapat dijelaskan bahwa analisis multivariate diperoleh faktor dominan berhubungan dengan kemampuan menemukan makna spiritual pengalaman sakit adalah variabel infeksi oportunistik karena mempunyai odds ratio yang lebih besar dibanding variabel jenis kelamin.

\section{PEMBAHASAN}

Rata-rata responden berusia 34,84 tahun, termuda 21 tahun dan tertua 49 tahun. Hasil uji independent $\mathrm{t}$ test ada hubungan antara usia dengan makna spiritual pengalaman sakit. Pada tahapan usia merupakan proses yang matang dan berpengaruhnya semua nilai-nilai agama dalam aspek kehidupan, agama sebagai jalan hidup, menemukna jati diri, menentukan jalan hidup dan mengadopsi norma yang ada disekitarnya (Sari, 2020). Sikap keberagamaan cenderung mengarah kepada tipe kepribadian masing-masing, namun kapasitas diri, pengalaman, dan lingkungan sangat berpengaruh terhadap sikap religius dan spiritual (Amin et al., 2019; Iswati, 2018).

Indikator agama/religi merupakan hal yang sangat dibutuhkan ketika pasien HIV berada dalam kondisi sakit, energi akan habis ketika mengalami gangguan imunitas, semangat untuk memaknai hidup positif akan berkurang. Aspek spiritual dapat meningkatkan koping, mempromosikan perilaku sehat, mengurangi depresi dan kecemasan (Amal \& Khofsoh, 2018; Amin \& Lestari, 2020).

Mayoritas responden berjenis kelamin laki-laki, hasil uji chi square menunjukkan tidak ada hubungan antara jenis kelamin dengan kemampuan menemukan makna spiritual pengalaman sakit. Laki-laki lebih banyak dibanding perempuan, hal ini sejalan dengan apa yang disampaikan oleh (Kemenkes RI, 2018; Saktina \& Satriyasa, 2017; UNAIDS, 2019). Sarvasti (2020) menyampaikan bahwa laki-laki mempunyai tingkat keparahan, prevalensi dan patogensis infeksi yang tinggi yang disebabkan oleh virus, bakteri ataupun jamur. Struktur genomic membedakan antara laki-laki dan perempuan, laki-laki mempunyai satu kromosom $\mathrm{X}(\mathrm{XY})$ sedangkan perempuan mempunyai dua kromosom X (XX). Kromosom X terlibat dalam sistem imun innate dan adaptif, mempunyai efektor yang berfungsi mengontrol proses transkripsi dan translasi untuk mengaktifkan reseptor sitokinin, mengontrol mekanisme noncoding micro ribonucleic acid (miRNA), mengandung 10\% miRNA total yang terlibat dalam ekpresi gen dengan cara menghambat translasi RNA dengan cara mencetuskan degradasi RNA. Kromosom X membawa gen imun penting termasuk Toll Like - receptor 7 (TLR-7) yang mengkode sensor pathogen, studi lain mengkonfirmasi bahwa esterogen bersifat represif terhadap perkembangan dari fase laten dan blokade dari reseptor esterogen dapat meningkatkan reaktivasi, studi lainnya menjelaskan bahwa reseptor esterogen diidentifikasi sebagai inhibitor potensial transkripsi HIV dalam fase laten (Aurelina, 2020). Inilah yang membuat laki-laki lebih rentan terhadap infeksi dibandingkan perempuan. Penelitian ini juga sejalan dengan penelitian Ilham et al., (2020) bahwa laki-laki memiliki jumlah infeksi sekunder lebih banyak, durasi rawat inap lebih lama dibandingkan dengan perempuan.

Mayoritas responden berpendidikan menengah (SMP dan SMA) analisis bivariate menyimpulkan tidak ada hubungan pendidikan terakhir dengan kemampuan menemukan makna spiritual pengalaman sakit. Gambaran responden memungkinkan kurangnya pengetahuan tentang penyakit HIV religius dan spiritual karena kurang terpapar informasi keagamaan, serta penyerapan informasi belum optimal (Anetor, 2019; Jayani \& Ruffaida, 2020). Religiusitas dan spiritualitas dapat meningkatkan kedamaian dan kebahagiaan, menumbuhkan kekuatan batin, menambah pemahaman terhadap penyakit dan penerimaan diri, meningkatkan motivasi perawatan diri, menemukan arti dan tujuan hidup, memelihara 
asa dan menciptakan hubungan dan rasa keterkaitan terhadap sesama dan yang lebih penting hubungan dan keterkaitan dengan Maha Pencipta (Chaiyasit et al., 2019).

Mayoritas responden bekerja sebagai buruh/karyawan swasta/wiraswasta/dagang. Hasil uji statistic regresi logistic sederhana menyimpulkan tidak ada hubungan antara pekerjaan dengan kemampuan menemukan makna spiritual pengalaman sakit. Peneliti berasumsi kurangnya keterikatan antara responden dengan perusahaan dan waktu kerja yang fleksible sangat memungkinkan responden menggunakan atau mengalihkan waktu untuk melakukan perilaku menyimpang yang beresiko terinfeksi HIV. Besarnya pendapatan menjadi pemicu melakukan apapun yang beresiko terinfeksi HIV. Wiraswastawan mempunyai mobilitas tinggi, sering berada di luar rumah dan berinteraksi dengan banyak orang, ini menjadi pemicu perilaku beresiko terinfeksi HIV, sementara buruh lebih banyak menghabiskan waktu di luar rumah, baik itu bekerja dalam shift atau paruh waktu. Waktu yang dihabiskan untuk melakukan aktivitas bahkan terabaikan, ketergantungan terhadap Tuhan pun terlupakan, segala sesuatu dipikirkan berdasarkan keduniawian tanpa menghiraukan sandaran vertikal dengan Tuhan (Saktina \& Satriyasa, 2017). Hal ini sejalan dengan tulisan Khusnah (2019) orang yang mempunyai spiritualitas tinggi mempunyai komitmen budaya organisasi yang tinggi dan memberi pengaruh positif terhadap kinerja pada perusahaan tempat kerja.

Mayoritas responden beragama Islam, hasil uji analisis chi square menyimpulkan tidak ada hubungan antara agama dengan kemampuan menemukan makna spiritual pengalaman sakit. Religiusitas memberikan pengaruh terhadap penerimaan diri ODHA, semakin tinggi tingkat religius, semakin tinggi tingkat husnudzon kepada Sang Maha Pencipta, semakin tinggi penerimaan diri terhadap sakit yang diderita (Anwar, 2020). Andrianto et al., (2019)dalam penelitiannya menjelaskan bahwa ketika seorang muslim menjalankan praktik keagamaan dengan baik, membuat ODHA muslim menerima dirinya, pasrah dengan tetap berusaha untuk sehat, selalu berbaik sangka dan berpikir positif tentang penyakit yang dideritanya. Untuk mencapai semua itu peran praktisi kesehatan sangat penting untuk membantu memulihkan, meningkatkan religiusitas dan spiritualitas ODHA (Roger \& Hatala, 2018).

Mayoritas responden berpendapatan dibawah Rp. 4 juta/bulan, hasil uji chi square menyimpulkan tidak ada hubungan antara status ekonomi dengan kemampuan menemukan makna spiritual pengalaman sakit. Ada keterkaitan antara pendidikan terakhir, pekerjaan dan pendapatan. Pendidikan terakhir menentukan seseorang mendapatkan pekerjaan dan pekerjaan menentukan besaran pendapatan (Krause et al., 2017).

Pendapatan merupakan salah satu indikator status ekonomi. Pendapatan yang tinggi membuat seseorang leluasa untuk melakukan apapun, termasuk menjadikan gaya hidup beresiko perilaku menyimpang. Pendapatan yang rendah pun menjadi pemicu terjadinya perilaku menyimpang, keadaan ekonomi dibawah rata-rata, menyebabkan seseorang mengerjakan apa saja yang mampu mendatangkan tambahan penghasilan. Petuah-petuah agama dan pesan-pesan normative tidak lagi dipedulikan, yang penting kebutuhan dapat terpenuhi tanpa memikirkan dari mana jalan mendapatkannya (Mukti et al., 2019). Sulit meyakini bahwa Tuhan Maha baik, karena minimnya sumber daya spiritual, ada keengganan untuk melakukan koping strategi spiritual (Krause et al., 2017).

Sebagian besar responden menikah, hasil analisis statistik chi square menunjukkan tidak ada hubungan antara status perkawinan dengan kemampun menemukan makna spiritual pengalaman sakit. Banyaknya ODHA berstatus menikah disebabkan tertular dari pasangannya yang terinfeksi HIV (Saktina \& Satriyasa, 2017). Keyakinan spiritual membantu individu menciptakan ikatan emosional yang dapat meningkatkan kepuasan perkawinan, 
spiritualitas membantu mengenali diri sendiri, mengembangkan emosi positif dan puas dengan kehidupan yang dijalani (Kasapoğlu \& Yabanigül, 2018).

Responden rata-rata sudah terdiagnosa HIV 4,49 tahun, hasil uji statistik menunjukkan tidak ada hubungan antara awal diagnosa dengan kemampuan menemukan makna spiritual pengalaman sakit. Pada tahun pertama terdiagnosa HIV, ODHA mengalami kecemasan terhadap kematian (Widianti, 2018). Perubahan religious yang positif terjadi setelah dinyatakan positif terinfeksi HIV (Prasojo, 2017). Hasil penelitian ini juga sejalan dengan penelitian yang dilakukan oleh Jayani \& Ruffaida (2020) yang menyebutkan bahwa 45\% responden mengalami peningkatan spiritual positif setelah terdiagnosa HIV.

Mayoritas responden tidak mengalami kejadian infeksi oportunistik, hasil uji chi square menyimpulkan tidak ada hubungan antara kejadian infeksi oportunistik dengan kemampuan menemukan makna spiritual pengalaman sakit. Agustin (2018) yang menyatakan bahwa tingkat spiritualitas yang tinggi dapat membuat ODHA hidup lebih tertata dan teratur, sehingga dapat meningkatkan imunitas yang pada akhirnya meningkatkan kualitas hidup ODHA.

Mayoritas responden mempunyai tingkat kepatuhan minum obat tinggi, hasil uji regresi logistic sederhana menunjukkan tidak ada hubungan antara kepatuhan minum obat dengan kemampuan menemukan makna spiritual pengalaman sakit. Kepatuhan minum obat pada pada penelitian ini belumlah optimal, walaupun mayoritas tetapi proporsi tidak jauh beda dengan responden yang memiliki tingkat kepatuhan sedang dan rendah, masih ada celah untuk terjadinya resistensi ARV dan rentan terjadinya kondisi kesehatan memburuk, munculnya infeksi oportunistik bahkan kematian (Dalmida et al., 2017).

Semua ODHA mempunyai keinginan untuk mengikuti program pengobatan dengan baik, tetapi efek samping ARV membuat tidak nyaman, banyak ODHA drop out, situasi ini menjadi fenomena sebagian besar ODHA, perlu dukungan dari keluarga (Beyene Gebrezgiabher et al., 2019) kelompok agama, kelompok sebaya, akses pelayanan kesehatan (Lasti, 2017). Hal ini sejalan dengan penelitian yang dilakukan oleh (Dalmida et al., 2017) menyimpulkan ada hubungan antara dukungan sosial dengan kepatuhan minum ART. Motivasi spiritual memberi keyakinan mendalam yang positif, proses adaptasi terhadap penyakit menyadarkan bahwa dirinya terinfeksi HIV, mewajibkan untuk patuh minum obat sebagai usaha menjaga kestabilan kesehatan (Umah \& Irawanto, 2019).

Mayoritas responden mengalami cemas dan depresi ringan, hasil uji regresi logistic menyimpulkan tidak ada hubungan antara cemas dan depresi dengan kemampuan menemukan makna spiritual pengalaman sakit. Depresi muncul sebagai dampak stigma dan diskriminasi masyarakat yang menilai bahwa ODHA adalah manusia pendosa, sedangkan dihukum karena perbuatannya sehingga harus dijauhi, hal ini sangat menyulitkan ODHA untuk melakukan aktivitas yang biasa dikerjakan sebelum terinfeksi HIV, situasi ini berdampak pada psikologi ODHA, mereka merasakan penyesalan yang mendalam, marah, kecewa, bingung, putus asa dan tidak mempunyai harapan lagi untuk masa depan. Religiusitas berperan dalam mengurangi depresi (Prasojo, 2017). Peneliti berasumsi, semakin kecil tingkat cemas dan depresi, ODHA semakin mampu menemukan makna spiritual pengalaman sakit positif dan dukungan sosial terutama religiusitas dan spiritualitas sangat bermanfaat dalam meminimalisir terjadinya depresi.

Hasil analisis multivariate diperoleh infeksi oportunistik merupakan faktor dominan berhubungan dengan kemampuan menemukan makna spiritual pengalaman sakit. Motivasi yang tinggi untuk berperilaku sehat dan percaya diri bahwa penyakit akan sembuh bila mengikuti program pengobatan berpengaruh terhadap perilaku patuh terhadap pengobatan yang pada akhirnya dapat mengurangi kejadian infeksi oportunistik (Kim et al., 2019). 
Penyakit penyerta/infeksi oportunistik muncul beberapa tahun setelah terinfeksi HIV, psikologis pasien semakin terguncang dan sakitpun semakin dalam dirasakan. Rasa sakit (illness) merupakan respon psikis berakibat melemahnya daya tahan tubuh sehingga mempersulit penyembuhan, pikiran dan emosi terlibat dalam proses pemaknaan diri terhadap sakit, berpengaruh terhadap kondisi fisik. Selain pengetahun dan pengalaman, keimanan terhadap Allah SWT memberi keyakinan bahwa Allah memberikan kesembuhan dan selalu mengambil hikmah dibalik sakit. Kejadian infeksi oportunistik membuat ODHA cemas dan depresi, karena infeksi oportunistik menjadi penyebab terbesar kematian pada ODHA (Yuliyanasari, 2017). Dukungan religiusitas dan spiritualtas tinggi sangat membantu dalam meningkatkan kepatuhan minum obat untuk mencegah terjadinya perburukan kondisi kesehatan ODHA (Badanta-Romero et al., 2018).

Dalam penelitian ini ditemukan sebagian besar responden beragama Islam $(92,4 \%)$ dengan rata-rata 34,84 tahun yang dapat menemukan makna spiritual pengalaman sakit positif adalah rata-rata usia 35,52 tahun, artinya di atas rata-rata responden secara keseluruhan, pada usia tersebut mayoritas menyadari bahwa hidupnya harus banyak mendekatkan diri dengan Tuhan. Spiritualitas mempunyai arti penerimaan dan kepasrahan kepada Tuhan namun disertai usaha dan ikhtiar untuk mendapatkan kesembuhan, mendekatkan diri dan meningkatkan taqwa kepada Allah merupakan strategi koping religius dengan cara mengembalikan hubungan dengan Allah, melakukan perubahan besar pada diri sendiri setelah menderita penyakit terlebih setelah munculnya infeksi oportunistik (Andrianto et al., 2019). Peneliti berasumsi dengan koping religious yang baik akan memberikan dampak pemaknaan sakit positif.

\section{SIMPULAN}

Faktor infeksi oportunistik merupakan faktor dominan berhubungan dengan kemampuan menemukan makna spiritual pengalaman sakit.

\section{SARAN}

Perlu menerapkan asuhan keperawatan spiritual dalam pemberian pelayanan keperawatan, perlu mengintegrasikan pendidian keperawatan yang berbasis spiritual, perlu penelitian lebih lanjut yang lebih spesifik pada responden yang baru terdiagnosa dan lama terdiagnosa karena tingkat cemas pada responden ini berbeda.

\section{DAFTAR PUSTAKA}

Agustin, L. (2018). Hubungan antara Siritualitas dengan Kualitas Hidup pada orang dengan HIV/AIDS [Universitas Islam Indonesia]. https://dspace.uii.ac.id/bitstream/handle/123456789/6337/

Amal, A. I., \& Khofsoh, E. (2018). Potret Kebutuhan Spiritual Pasien HIV / AIDS. Unissula Press, 1(1), 70-74. http://jurnal.unissula.ac.id/index.php/unc/article/download/2889/2103

Amin, M., Fredrika, L., \& Kartika, D. D. (2019). Pengalaman dan Gangguan Aktivitas Seksualitas Klien Penyakit Jantung Koroner. Jurnal Kesmas Asclepius, 1(2), 186195. https://doi.org/10.31539/jka.v1i2.967

Amin, M., \& Lestari, Y. A. (2020). Pengalaman Pasien Vertigo di Wilayah Kerja Puskesmas Lingkar Timur. Jurnal Kesmas Asclepius, 2(1), 22-33. https://doi.org/10.31539/jka.v2i1.1087 
Andri, J., Ramon, A., Padila, P., Sartika, A., \& Putriana, E. (2020). Pengalaman Pasien ODHA dalam Adaptasi Fisiologis. Journal of Telenursing (JOTING), 2(2), 127141. https://doi.org/10.31539/joting.v2i2.1397

Andrianto, M. B., Mendrofa, F. A. M., \& Muin, M. (2019). Hubungan Praktek Keagamaan Islam dengan Koping Religius pada Kelompok Penderita HIV/AIDS di Wilayah Kabupaten Temanggung. 6(2), 129-133. https://doi.org/DOI:http://dx.doi.org/10.34310/jskp.v6i2.270

Anetor, G. (2019). Influence of Gender and Demographic Variables on Awareness of Secondary School Students on HIV/AIDS Infection in Abuja, Nigeria. Journal of Applied Sciences and Environmental Management, 23(1), 47. https://doi.org/10.4314/jasem.v23i1.8

Anwar, N. (2020). Husnudon dan Penerimaan Diri pada Orang dengan HIV/AIDS (ODHA) [Universitas Islam Indonesia]. https://dspace.uii.ac.id/bitstream/handle/123456789/23785/16320093 Nadilah Anwar.pdf

Aurelina, R. (2020). Faktor-Faktor yang Berhubungan terhadap Kadar Cluster of Differentiation4 (CD4) pada pasien HIV/AIDS. Jurnal Medika Hutama, 02(01), 308-313. http://jurnalmedikahutama.com/index.php/JMH/article/view/96

Badanta-Romero, B., de Diego-Cordero, R., \& Rivilla-García, E. (2018). Influence of Religious and Spiritual Elements on Adherence to Pharmacological Treatment. Journal of Religion and Health, 57(5), 1905-1917. https://doi.org/10.1007/s10943-018-0606-2

Beyene, G. B., Huluf, A. T., Hailu, E., Siyum, H., Mebrahtu, G., Gidey, B., Abay, M., Hintsa, S., \& Angesom, T. (2019). Depression among Adult HIV/AIDS Patients Attending ART Clinics at Aksum Town, Aksum, Ethiopia: A Cross-Sectional Study. Depression Research and Treatment, 2019. https://doi.org/10.1155/2019/3250431

Chaiyasit, Y., Thong-on, R., Piboonrungroj, P., \& Kotta, P. (2019). The Roles of Spirituality in People Living With Hiv/Aids: a Qualitative Meta-Synthesis. The Bangkok Medical Journal, 15(1), 113-120. https://doi.org/10.31524/bkkmedj.2019.02.020

Dalmida, S. G., McCoy, K., Koenig, H. G., Miller, A., Holstad, M. M. D., Thomas, T., Clayton-Jones, D., Grant, M., Fleming, T., Wirani, M. M., \& Mugoya, G. (2017). Examination of the Role of Religious and Psychosocial Factors in HIV Medication Adherence Rates. Journal of Religion and Health, 56(6), 2144-2161. https://doi.org/10.1007/s10943-017-0377-1

Ilham, M., Triliana, R., \& Tilaqza, A. (2020). Pengaruh Usia, Gender, Pekerjaan, dan Pembeayaan Kesehatan terhadap Jumlah Rawat Inap dan Infeksi Sekunder pada Pasien HIV di Rumah Sakit X Kota Malang. Jurnal Bio Komplementer Medicine, 7(1), 1-9. http://riset.unisma.ac.id/index.php/jbm/article/view/6638/0

Iswati, I. (2018). Karakteristik Ideal Sikap Religiusitas pada Masa Dewasa. At-Tajdid: Jurnal Pendidikan dan Pemikiran Islam, 02(01), 58-71. https://doi.org/10.24127/att.v2i01.859

Jayani, I., \& Ruffaida, S. F. (2020). Pengaruh Pendekatan melalui Konseling Interpersonal terhadap Respon Sosial, Emosional dan Spiritual pada Pasien HIV/AIDS. Ilmiah Ilmu Kesehatan, 8(1), 62-73 
Kasapoğlu, F., \& Yabanigül, A. (2018). Marital Satisfaction and Life Satisfaction: The Mediating Effect of Spirituality. Spiritual Psychology and Counseling, 3(2), 177195. https://doi.org/10.37898/spc.2018.3.2.0048

Kemenkes RI. (2018). InfoDatin-HIV-AIDS-2018 (p. 12)

Khusnah, H. (2019). Pengaruh Spiritualitas di Tempat Kerja, Komitmen Organisasi dan Kepuasan Kerja terhadap Kinerja Karyawan. Jurnal Ilmiah Akuntansi, 17(1), 1121. http://jurnalnasional.ump.ac.id/index.php/kompartemen/article/view/2825

Kim, S., Kim, E., \& Ryu, E. (2019). Illness Perceptions, Self-Care Management, and Clinical Outcomes According to Age-Group in Korean Hemodialysis Patients. International Journal of Environmental Research and Public Health, 16(22). https://doi.org/10.3390/ijerph16224459

Krause, N., Pargament, K. I., \& Ironson, G. (2017). Spiritual Struggles and Health: Assessing the Influence of Socioeconomic Status. Journal for the Scientific Study of Religion, 56(3), 620-636. https://doi.org/10.1111/jssr.12364

Lasti, M. H. (2017). Analisis Kepatuhan Minum Obat Anmtiretriviral (ARV) pada Komunitas LSL (laki-Laki Sex dengan Laki-Laki) di Kota Parepare Sulawesi Selatan. In Journal of Chemical Information and Modeling. https://doi.org/10.1017/CBO9781107415324.004

Lin, Y. C., Dhaliwal, J. S., Kong, A. Z. H., Chan, L. G., \& Tan, P. L. L. (2017). HIVRelated Stigma as Perceived by HIV-Positive Individuals in Singapore. HIV \& AIDS Review, 3(3), 176-182. https://doi.org/10.5114/hivar.2017.70711

Mahaendriningtiyastuti, M., Yani, E. R., \& Suwoyo, S. (2018). Stigma dan Diskriminasi Serta Strategi Koping pada Orang Dengan Hiv/Aids di Kota Ambon. Global Health Science, 3(1), 339-345

Mukti, A., Nasution, A. S., \& Lubis, S. (2019). Peran Pendidikan Agama Islam dalam Menghempang Perilaku Lesbian Gay Biseksual Transgender di Kota Medan. Attazakki, 3(1), 143-159

Prasojo, D. (2017). Peran Religiusitas pada Penderita HIV dan AIDS yang Mengalami Depresi. Jurnal Studia Insania, 5(1), 46-70. https://doi.org/10.18592/jsi.v5i1.1270

Purwandari, P., Nila, P., Johan, A., \& Sujianto, U. (2019). Pengalaman Interaksi Sosial Orang dengan HIV dalam Menghadapi Stigma Sosia HIV/AIDS

Roger, K. S., \& Hatala, A. (2018). Religion, Spirituality \& Chronic Illness: A Scoping Review and Implications for Health Care Practitioners. Journal of Religion and Spirituality in Social Work, 37(1), 24-44. https://doi.org/10.1080/15426432.2017.1386151

Saktina, P., \& Satriyasa, B. (2017). Karakteristik Penderita Aids dan Infeksi Oportunistik di Rumah Sakit Umum Pusat Sanglah Denpasar Periode Juli 2013 Sampai Juni 2014. E-Jurnal Medika Udayana, 6(3), 1-6. https://ojs.unud.ac.id/index.php/eum/article/view/29100

Sari, N. K. (2020). Dinamika Perkembangan Spiritualitas dan Relevansinya terhadap Pendidikan Islam. Tadbir: Jurnal Manajemen Pendidikan Islam, 8(1), 53-65. https://doi.org/10.30603/tjmpi.v8i1.735

Sarkar, T., Karmakar, N., Dasgupta, A., \& Saha, B. (2019). Stigmatization and Discrimination Towards People Living with HIV/AIDS Attending Antiretroviral Clinic in a Centre of Excellence in HIV Care in India. International Journal of Community Medicine And Public Health, 6(3), 1241. https://doi.org/10.18203/2394-6040.ijcmph20190619 
Sarvasti, D. (2020). Pengaruh Gender dan Manifestasi kardiovaskuler pada Covid-19. Indonesian J Cardiol, 41(2), 125-132. https://doi.org/10.30701/ijc.1004

Sididi, M., Rahman, R., \& Yusriani, Y. (2020). High Risk Behaviour Tertular HIV/AIDS pada Anak Buah Kapal. Jurnal Kesmas Asclepius, 2(2), 88-96. https://doi.org/10.31539/jka.v2i2.1470

Syahrina, I. A., \& Pranata, A. Y. (2018). Stigma Internal Hubungannya dengan Interaksi Sosial Orang dengan HIV/AIDS di Yayasan Taratak Jiwa Hati Padang. Jurnal Fakultas Psikologi Universitas Wisnuwardhana Malang, 22, 1-17

Umah, K., \& Irawanto, D. (2019). Motivasi Spiritual Meningkatkan Kepatuhan Minum Obat ARV pada Pasien Hiv / Aids (Spiritual Motivation to Improve ARV Drug Compliance in Hiv / Aids Patients). Journal of Ners Community, 10(2), 251-263. http://journal.unigres.ac.id/index.php/JNC/article/download/919/771

UNAIDS. (2019). Global HIV and AIDS statistics | AVERT. Averting HIV And Aids, 6-12. http://www.avert.org/professionals/hiv-around-world/global-statistics

Wicaksono, Y. A., Fitrikasari, A., Sofro, M. A. U., \& Peni, H. (2018). Hubungan Stigma dan Terapi ARV dengan Komplikasi Gangguan Psikiatri pada Pasien HIV/AIDS. Jurnal Penyakit Dalam Indonesia, 5(1), 24. https://doi.org/10.7454/jpdi.v5i1.161

Widianti, E. (2018). Tingkat Kecemasan terhadap Kematian pada ODHA. Jurnal Keperawatan Soedirman, 12(3), 199. https://doi.org/10.20884/1.jks.2017.12.3.758

Yuliyanasari, N. (2017). Global Burden Disease - Human Immunodeficiency Virus Acquired Immune Deficiency Syndrome (HIV-AIDS). 1(1), 65-77. http://journal.um-surabaya.ac.id/index.php/qanunmedika/article/view/385 